\title{
Breve balanço de nossa atuação na presidência do CBO
}

\author{
Marcos Ávila*
}

Em 2001 o Conselho Brasileiro de Oftalmologia completou 60 anos de existência. Um pouco menos do que o ABO fundado alguns anos antes. Nestas décadas, o mundo transformouse de forma surpreendente e atualmente as duas instituições, entrelaçadas, são partes fundamentais dos alicerces deste grande edifício que chamamos de Oftalmologia Brasileira.

Os Arquivos Brasileiros de Oftalmologia, sem dúvida uma das melhores publicações científicas do Brasil, representam de forma clara a preocupação científica do $\mathrm{CBO}$, que também se manifesta no monitoramento constante dos cursos de especialização em oftalmologia, na realização criteriosa das Provas Nacionais de Oftalmologia e dos Exames de Habilitação ao Título de Especialista, na promoção dos grandiosos congressos brasileiros de oftalmologia e de prevenção da cegueira e reabilitação visual, na criação de mecanismos que possibilitem a educação continuada do Médico Oftalmologista, entre outras atuações.

Porém, as exigências do mundo atual fizeram com que o CBO tivesse que ampliar seu raio de ação e agir em setores que, inicialmente, não faziam parte de sua filosofia. Assim, o Conselho passou a atuar na coordenação de Campanhas de Prevenção da Cegueira e Reabilitação Visual, notadamente nos campos da cirurgia de catarata, no exame oftalmológico das crianças que entram na vida escolar e no tratamento da retinopatia diabética, que teve como resultado permanente a criação de 33 Centros de Referência no tratamento da doença em todo o Brasil. Foram iniciativas da Oftalmologia Brasileira que posteriormente foram abraçadas pelo poder público e resultaram no estabelecimento de parcerias cada vez mais produtivas para a saúde ocular da população. No futuro, tais iniciativas serão ampliadas e diversificadas, contribuindo decisivamente para o aumento do prestígio social e político dos oftalmologistas de nosso País.
Existe ainda um terceiro grande campo de atuação do CBO, que nos últimos anos mereceu nossa especial atenção: a defesa das prerrogativas profissionais do médico oftalmologista. Mesmo correndo o risco de gerar polêmicas e sofrer desgastes, entendemos que lutar por melhores condições de trabalho para aqueles que praticam a Oftalmologia e garantir que o cuidado primário da visão continue sendo um ato médico é o complemento imprescindível da atuação de nossa entidade máxima.

Aqueles que detém o conhecimento científico, devem também lutar para que seu conhecimento seja utilizado pela sociedade da melhor forma possível, que provoque os maiores benefícios para o maior número de Seres Humanos. Esta é a essência de nossa Ética e, sem descuidarmos um milímetro de nossas preocupações com o aprimoramento científico, temos que lutar cada vez mais para que ele seja um bem social, compartilhado de forma justa, mesmo que para isto tenhamos que lutar contra a política por vezes inadequada de algumas empresas intermediadoras da assistência médica.

Em nossa gestão na presidência do CBO procuramos integrar de forma cada vez mais sólida essas três frentes de atuação, encarando-as como partes de um conjunto indivisível. Através do diálogo democrático com todos os setores que a ele se prestaram, procuramos aumentar a inserção social e política da nossa oftalmologia para gerar benefícios para os especialistas e, desta forma, atingir nosso maior objetivo: melhorar a saúde ocular do nosso paciente e colocar a ciência desenvolvida pela oftalmologia, tão brilhantemente exposta na publicação que temos em mão, a serviço da maioria da população. Neste caminho, seguimos os passos daqueles que vieram antes de nós e sabemos que serão seguidos pelos que estão por vir. 